\title{
$\mathrm{Alpha}_{1}$ antitrypsin deficiency and pulmonary emphysema
}

\author{
M. C. JONES and G. O. THOMAS
}

Brompton Hospital, London S.W.3

\begin{abstract}
An association between a genetically determined deficiency of the serum enzyme $\alpha_{1}$ antitrypsin and pulmonary emphysema is now well established. Serum antitryptic activity was measured in 103 patients suspected of having emphysema. Eighty-seven fulfilled the diagnostic criteria for emphysema and, of these, 16 had deficient levels, 5 had intermediate levels, and 66 had normal levels. The results of clinical, radiographic, and physiological studies in each group were then compared. Characteristic features noted in the deficient group included onset of dyspnoea during the third or fourth decades and uniformly symmetrical radiographic lower zone involvement. Other factors such as sex distribution, cigarette smoking, and chronic bronchitis are discussed.

Sixty-eight relatives of the 16 patients with deficient levels were also studied. The findings in these are compatible with an autosomal recessive mode of inheritance although difficulties in identifying the heterozygous state were encountered. Six relatives had deficient levels and of these three had emphysema.
\end{abstract}

Emphysema is most commonly diagnosed in men with chronic bronchitis in the fifth or sixth decades (Talamo, Blennerhassett, and Austen, 1966). Cigarette smoking and recurrent pulmonary infection have been suggested as important aetiological factors, but although the occurrence of emphysema in families has been recognized since the early nineteenth century (Louis, 1837) there has, until recently, been little direct evidence about genetic factors.

Laurell and Eriksson in 1963 and Eriksson in 1965 first described an association between chronic obstructive pulmonary disease and a genetically determined deficiency of $\alpha_{1}$ antitrypsin, the chief component of $\alpha_{1}$ globulin. Family studies revealed a trimodal distribution of $\alpha_{1}$ antitrypsin serum levels with normal, intermediate (approximately $60 \%$ of normal), and deficient (less than $15 \%$ of normal) levels, compatible with the hypothesis of an autosomal recessive mode of inheritance. The homozygotes for the deficiency gene were found to have a high incidence of emphysema, while the heterozygotes, classed as those with intermediate levels, did not show this association. These findings have since been confirmed both in the United States and in Europe, though the exact role of the heterozygous state is undecided.

This paper presents the findings in a selected series of patients attending the Brompton Hospital with chronic respiratory disease in whom levels of serum antitryptic activity were estimated.

\section{DIAGNOSIS OF EMPHYSEMA}

Emphysema is defined on an anatomical basis as a disease characterized by structural changes in the lung causing increase, beyond the normal $\underset{\sim}{\tilde{D}}$ range, in the size of air spaces distal to terminal $\frac{0}{6}$ bronchioles (Scadding, 1969). In life, however, histopathological specimens are not usually avail- $\delta$ able and therefore the diagnosis depends on clinical, radiological, and physiological criteria. 은 For the purpose of this study the following radio- $>$ logical and physiological criteria were adopted, 을 the former having been shown to be strongly $N$ correlated with moderate to severe emphysema o (Reid and Millard, 1964):

1. Radiological (Simon, 1964).

(a) Low flat diaphragm

(b) Large retrosternal translucent zone

(c) Attenuation of the larger intrapulmonary vessels

(d) Dilated hilar arteries

2. Physiological

(a) Decrease in forced expiratory volume in $\frac{\stackrel{\circ}{\oplus}}{\Phi}$ one second $\left(\mathrm{FEV}_{1}\right)$ and $\mathrm{FEV}_{1} / \mathrm{FVC} \%$ $(<60 \%)$ 
(b) Increase in residual volume (RV), total lung capacity (TLC), and RV/TLC\% $(>45 \%)$

(c) Impaired gas transfer (TLco).

\section{DIAGNOSIS OF CHRONIC BRONCHITIS}

Simple chronic bronchitis is defined as a chronic or recurrent increase in the volume of mucoid bronchial secretion sufficient to cause expectoration (Lancet, 1965). For the purpose of this study the diagnosis was applied to any patient who had coughed up sputum on most days during at least three consecutive months for more than two successive years.

\section{MATERIAL}

Serum antitryptic activity was measured in the following:

CONTROLS Eighty-seven subjects consisting of 39 healthy blood donors, 35 members of the hospital staff, and 13 patients who had non-respiratory disease.

PATIENTS One hundred and three selected patients attending the Brompton Hospital between 1966 and 1969 and suspected of having emphysema. Eighty-seven of these fulfilled the diagnostic criteria for emphysema. The remaining 16 patients comprised nine with chronic bronchitis, four with asthma, one with obliterative bronchiolitis, one with pulmonary hypoplasia, and one with systemic lupus erythematosus.

RELATIVES Sixty-eight relatives of the 16 patients found to have deficient $\alpha_{1}$ antitrypsin levels were studied. Brief clinical details were obtained in each case.

\section{METHODS}

LABORATORY The following investigations were performed:

(a) Cellulose acetate serum electrophoresis was performed on all samples from patients.

(b) The serum antitryptic activity was measured in all cases by the trypsin inhibitory capacity (T.I.C.) method described by Eriksson (1965) using benzoylarginine- $p$-nitroanilide as a synthetic substrate. The $p$-nitroaniline released by tryptic hydrolysis is measured colorimetrically. The inhibitory action of serum on this reaction is expressed as milligrams of trypsin inhibited per millilitre of serum. The T.I.C. results were classified according to Eriksson's criteria as follows:

$$
\begin{array}{ll}
\text { Deficient } & <0.4 \mathrm{mg} / \mathrm{ml} \\
\text { Intermediate } & >0.4-0.8 \mathrm{mg} / \mathrm{ml} \\
\text { Normal } & >0.8 \mathrm{mg} / \mathrm{ml}
\end{array}
$$

In 39 of the 68 relatives $\alpha_{1}$ antitrypsin levels were also measured by agar gel immunodiffusion (Mancini, Vaerman, Carbonara, and Hermans, 1964) using rabbit anti- $\alpha_{1}$ antitrypsin antiserum (Behringwerke). The following criteria were adopted:

$$
\begin{array}{ll}
\text { Deficient } & <100 \mathrm{mg} \% \\
\text { Intermediate } & 100-200 \mathrm{mg} \% \\
\text { Normal } & >200 \mathrm{mg} \%
\end{array}
$$

CLINICAL The following investigations were performed on all patients with emphysema:

(a) Postero-anterior and lateral chest radiographs. Tomography was used in some cases for the identification of bullae and the study of blood vessel distribution.

(b) Detailed pulmonary function tests including static lung volumes, spirometry (before and after bronchodilator aerosol), and gas transfer factor (TLco). The latter was measured by the steady state method (MacNamara, Prime, and Sinclair, 1959) or, in a few cases, by the single breath technique (Ogilvie, Forster, Blakemore, and Morton, 1957). Approximately half the patients also had arterial blood gas estimations and regional lung function studies using xenon 133 (Mannell, Prime, and Smith, 1966).

\section{RESULTS}

LABORATORY RESULTS (Table I and Fig. 1)

T A B L E I

TRYPSIN INHIBITORY CAPACITY (T.I.C.)

\begin{tabular}{l|c|c|c|c|c}
\hline \multirow{2}{*}{ Group } & \multirow{2}{*}{ No. } & $\begin{array}{c}\text { Mean } \\
\text { Age }\end{array}$ & \multicolumn{3}{|c}{ T.I.C. (mg/ml) } \\
\cline { 5 - 6 } & & & Range & Mean & S.D. \\
\hline Controls & 87 & 43.7 & $0.63-2.06$ & 1.13 & \pm 0.30 \\
Deficient & 16 & 41.1 & $0.12-0.33$ & 0.32 & \pm 0.03 \\
Intermediate & 5 & 60.6 & $0.61-0.79$ & 0.72 & \pm 0.06 \\
Non-deficient & 66 & 53.0 & $0.81-1.94$ & 1.25 & \pm 0.30 \\
\hline
\end{tabular}

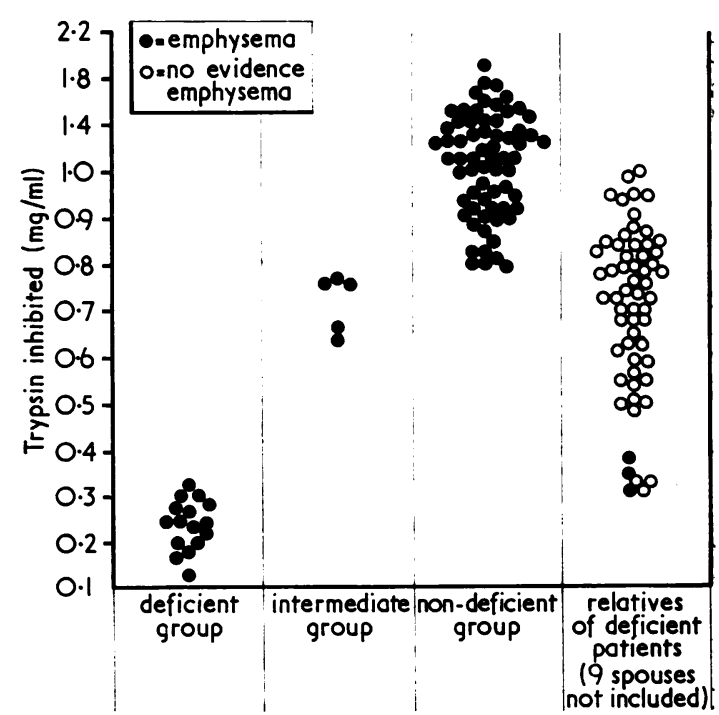

FIG. 1. Distributions of T.I.C. levels. 
Controls T.I.C. levels ranged from 0.63 to 2.06 $\mathrm{mg} / \mathrm{ml}$ with a mean of $1.13 \mathrm{mg} / \mathrm{ml}$ (S.D. \pm 0.30 $\mathrm{mg} / \mathrm{ml}$ ). Among these were three subjects who were pregnant (T.I.C. levels 2.06, 1.82, and 1.6 $\mathrm{mg} / \mathrm{ml}$ ) and three others with non-pulmonary carcinoma (T.I.C. levels $1.56,1.54$, and $1.20 \mathrm{mg}$ / $\mathrm{ml})$. Pregnancy and malignant disease are known to increase the serum $\alpha_{1}$ antitrypsin levels and therefore if these six are omitted, the mean T.I.C. becomes $1.09 \mathrm{mg} / \mathrm{ml}$ (S.D. $\pm 0.25 \mathrm{mg} / \mathrm{ml}$ ) which corresponds with Eriksson's results (mean $1.07 \pm$ $0.12 \mathrm{mg} / \mathrm{ml}$ ). Seven subjects had levels in the intermediate range; these were included in the calculation of the mean level for controls.

Patients Sixteen patients without emphysema all had T.I.C. levels of $0.85 \mathrm{mg} / \mathrm{ml}$ or above.

Eighty-seven patients with emphysema were divided according to their T.I.C. levels :

(a) Deficient group: sixteen patients came into this category with levels between 0.12 and 0.33 $\mathrm{mg} / \mathrm{ml}$ (mean $0.32 \mathrm{mg} / \mathrm{ml}$; S.D. \pm 0.03 ). All had a greatly diminished or absent $\alpha_{1}$ globulin zone on electrophoresis.

(b) Intermediate group: five patients had T.I.C. levels ranging from 0.61 to $0.79 \mathrm{mg} / \mathrm{ml}$ (mean $0.72 \pm 0.06)$. These showed a diminished $\alpha_{1}$ globulin zone on electrophoresis.

(c) Non-deficient group: the remaining 66 patients had levels between 0.81 and $1.94 \mathrm{mg} / \mathrm{ml}$ (mean $1.25 \mathrm{mg} / \mathrm{ml} \pm 0.30$ ) with normal electrophoretic strips.

Relatives of patients in deficient group (Table II) Sixty-eight relatives consisted of 9 parents, 9 spouses, 15 siblings, and 35 children. The latter included 21 children of index cases plus 6 children of two siblings also found to be $\alpha_{1}$ antitrypsin deficient and 8 children of two other siblings with intermediate T.I.C. levels.

Assuming from previous evidence (Eriksson, 1965) that the gene for $\alpha_{1}$ antitrypsin deficiency is transmitted as an autosomal recessive, the nine parents and 27 of the children examined may be regarded as 'genetic heterozygotes' unless any of the spouses of index cases also 'carry' the gene when some of the children might then be deficient homozygotes. In fact two children of case 4 had T.I.C. levels of $0.25 \mathrm{mg} / \mathrm{ml}$ and $0.35 \mathrm{mg} / \mathrm{ml}$ respectively, indicating that the spouse was probably a heterozygote despite a T.I.C. level of 0.82 $\mathrm{mg} / \mathrm{ml}$. The T.I.C. levels in the remaining 34 subjects ranged from 0.49 to $0.87 \mathrm{mg} / \mathrm{ml}$ with a mean of $0.73 \mathrm{mg} / \mathrm{ml}$ (S.D. \pm 0.115 ). (One parent with a level of $1.00 \mathrm{mg} / \mathrm{ml}$ was excluded because he was receiving oestrogen therapy.) Eight of the 34 genetic heterozygotes had levels between 0.80 and $0.87 \mathrm{mg} / \mathrm{ml}$ (included in a separate column in Table II) but in four of these $\alpha_{1}$ antitrypsin levels were estimated and found to be less than 200 $\mathrm{mg} \%(105 \mathrm{mg} \%, 180 \mathrm{mg} \%, 180 \mathrm{mg} \%$, and $195 \mathrm{mg} \%$ ).

Among the eight remaining children three had intermediate and five non-deficient T.I.C. levels. One of the latter had a level of $0.82 \mathrm{mg} / \mathrm{ml}$, but an $\alpha_{1}$ antitrypsin level of $110 \mathrm{mg} \%$ (intermediate).

Of the 15 siblings, four had deficient, five intermediate, and six non-deficient levels. Two of the six non-deficient siblings had T.I.C. levels of 0.87 and $0.89 \mathrm{mg} / \mathrm{ml}$. Both, however, had $\alpha_{1}$ antitrypsin levels of $170 \mathrm{mg} \%$ (intermediate range). If these two siblings are regarded as heterozygotes, the findings became compatible with a recessive mode of inheritance with four deficient homozygotes, seven heterozygotes, and four normal subjects corresponding to the predicted ratio of $1: 2: 1$.

The nine spouses all had non-deficient T.I.C. levels.

Thirty-nine relatives had both T.I.C. and $\alpha_{1}$ antitrypsin levels estimated. A good degree of correlation was found in 32 subjects, 3 with deficient, 15 with intermediate, and 14 with nondeficient levels recorded by each method. In the

T A B L E I I

T.I.C. LEVELS IN RELATIVES OF PROBANDS

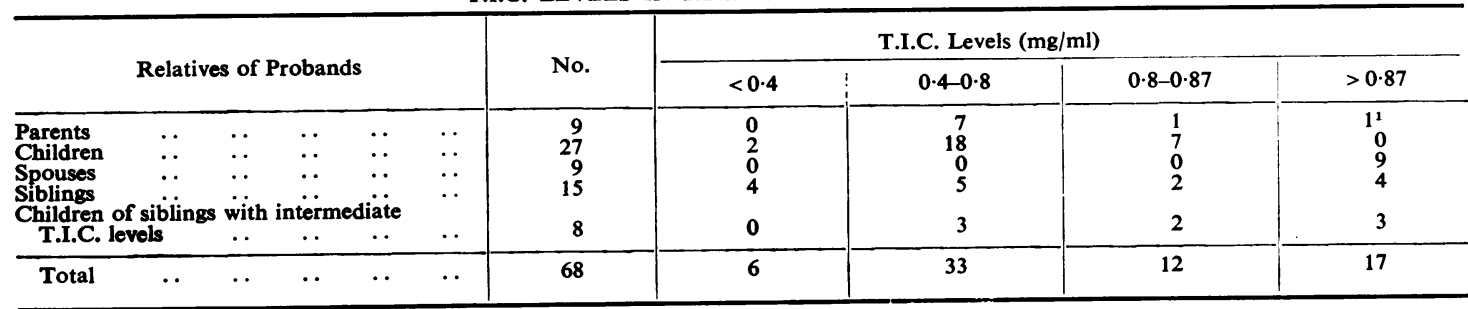

${ }^{1}$ On oestrogens. 
remaining seven relatives, referred to in the text above, four of whom were considered to be genetic heterozygotes, T.I.C. levels exceeded 0.80 $\mathrm{mg} / \mathrm{ml}$ (range $0.82-0.89 \mathrm{mg} / \mathrm{ml}$ ) whereas $\alpha_{1}$ antitrypsin levels were less than $200 \mathrm{mg} \%$ (range 105-195 mg\%). This discrepancy merely highlights the difficulty in identifying the heterozygous state.

\section{CLINICAL DETAILS OF EMPHYSEMA PATIENTS}

Sex (Table III) There were 76 male and 11 female patients (ratio $7: 1$ ). This ratio was the same in both the deficient (14 males and 2 females) and non-deficient (57 males and 9 females) groups. All five patients with intermediate levels were males.

Age (Table III) The mean age at presentation, i.e., when first referred to hospital, was appreciably lower in the deficient group of patients (41.1 years) than in the intermediate (60.6 years) or non-deficient (53.0 years) groups. Dyspnoea, based on the patient's history, developed on average three to five years before presentation in each group. Dyspnoea started at a mean age of 35.6 years in the deficient group of patients, all of whom were dyspnoeic before the age of 50 years (range 29-49 years). The mean age at onset of dyspnoea in the intermediate and non-deficient groups was 56.6 and 50.4 years respectively. Only 29 of these latter 71 patients were dyspnoeic before the age of 50 .

Sixty per cent of the emphysema patients whose dyspnoea began before the age of $\mathbf{4 0}$ years, $16 \%$ of those in whom it began between 40 and 49 years, and none of those in whom it began later were $\alpha_{1}$ antitrypsin deficient (Table IV). All five patients in the intermediate group became dyspnoeic after the age of 50 years.

Cigarette smoking (Table III) In the deficient group of patients only one was a non-smoker.
He did not develop dyspnoea until the age of 49 years, over 13 years above the mean age and 7 years later than any other patient in that group. There were 11 non-smokers ( 7 male and 4 female) in the non-deficient group and none in the intermediate group.

Chronic bronchitis (Table III) Sixty-eight of the 87 patients with emphysema had chronic bronchitis and all were cigarette smokers. In the deficient group $12(75 \%)$ had chronic bronchitis, symptoms of cough and sputum preceding dyspnoea in some cases. Excepting the nonsmoker in this group, there was no difference in the age at onset of dyspnoea or presentation between those with and those without chronic bronchitis.

Peptic ulcer (Table III) Evidence of peptic ulceration, based on recent or previous barium studies, was obtained in $12(13.7 \%)$ of all 87 patients, none being in the deficient group.

Radiographic findings (Table $\mathrm{V}$ and Fig. 2) In the deficient group the radiographic features of emphysema were marked. The distribution in every case was symmetrical, involving predominantly the lower zones. Bullae were seen in six $(37.5 \%)$, always in the lower zones. In the other groups the appearances were more variable, symmetry was less evident, and upper zone involvement was common. Bullae were present in 29 $(40.8 \%)$.

\section{T A B LE IV}

AGE AT ONSET OF DYSPNOEA IN EMPHYSEMA PATIENTS RELATED TO $a_{1}$ ANTITRYPSIN DEFICIENCY

\begin{tabular}{c|c|c|c}
\hline \multirow{2}{*}{$\begin{array}{c}\text { Age at Onset of } \\
\text { Dyspnoea (yr) }\end{array}$} & \multicolumn{2}{|c|}{ No. of Patients } & \multirow{2}{*}{ Deficient } \\
\cline { 2 - 3 } & Total & Deficient & \\
\hline$<40$ & 20 & 12 & 60 \\
$40-49$ & 25 & 4 & 16 \\
$>50$ & 42 & 0 & 0 \\
\hline
\end{tabular}

T A B L E I I I

CLINICAL DETAILS OF EMPHYSEMA PATIENTS

\begin{tabular}{|c|c|c|c|c|c|c|c|c|c|}
\hline \multirow{2}{*}{ Group } & \multirow{2}{*}{ No. } & \multirow{2}{*}{ Sex } & \multicolumn{2}{|c|}{ Age at Onset } & \multicolumn{2}{|c|}{$\begin{array}{c}\text { Age at } \\
\text { Presentation }\end{array}$} & \multirow{2}{*}{ Smoker } & \multirow{2}{*}{$\begin{array}{c}\text { Chroric } \\
\text { Bronchitis }\end{array}$} & \multirow{2}{*}{$\begin{array}{l}\text { Peptic } \\
\text { Ulcer }\end{array}$} \\
\hline & & & Range & Mean & Range & Mean & & & \\
\hline$\overline{\text { Deficient }}$ & 16 & $14 \mathrm{M}$ & $29-49$ & $35 \cdot 6$ & 33-59 & $41 \cdot 1$ & 15 & 12 & 0 \\
\hline Intermediate & 5 & $5 \mathrm{M}$ & $47-62$ & $56 \cdot 6$ & $50-64$ & $60 \cdot 6$ & 5 & 2 & 2 \\
\hline Non-deficient & 66 & $57 \mathrm{M}$ & $23-64$ & 50.4 & $31-73$ & 53 & 55 & 54 & 10 \\
\hline
\end{tabular}


T A B L E V

RADIOLOGICAL DISTRIBUTION OF EMPHYSEMA

\begin{tabular}{|c|c|c|c|c|c|c|c|c|c|}
\hline \multirow{3}{*}{ Group } & \multirow{3}{*}{ No. } & \multicolumn{5}{|c|}{ Emphysema } & \multicolumn{3}{|c|}{ Bullae } \\
\hline & & \multicolumn{3}{|c|}{ Widespread } & \multicolumn{2}{|c|}{ Limited } & \multirow{2}{*}{ Random } & \multirow{2}{*}{ U.Z. } & \multirow{2}{*}{ L.z. } \\
\hline & & $\begin{array}{l}\text { Mainly } \\
\text { U.Z. }\end{array}$ & $\begin{array}{c}\text { Mainly } \\
\text { L.Z. }\end{array}$ & Both & U.Z. & L.Z. & & & \\
\hline $\begin{array}{l}\text { Deficient } \\
\text { Intermediate } \\
\text { Non-deficient }\end{array}$ & $\begin{array}{l}16 \\
5 \\
66\end{array}$ & $\begin{array}{l}0 \\
0 \\
5\end{array}$ & $\begin{array}{r}7 \\
2 \\
17\end{array}$ & $\begin{array}{r}2 \\
1 \\
36\end{array}$ & $\begin{array}{l}0 \\
0 \\
6\end{array}$ & $\begin{array}{l}5 \\
2 \\
2\end{array}$ & $\begin{array}{l}0 \\
0 \\
3\end{array}$ & $\begin{array}{r}\mathbf{0} \\
\mathbf{0} \\
\mathbf{1 2}\end{array}$ & $\begin{array}{r}6 \\
13 \\
13\end{array}$ \\
\hline
\end{tabular}

U.Z. = upper zone; L.Z.= lower zone.

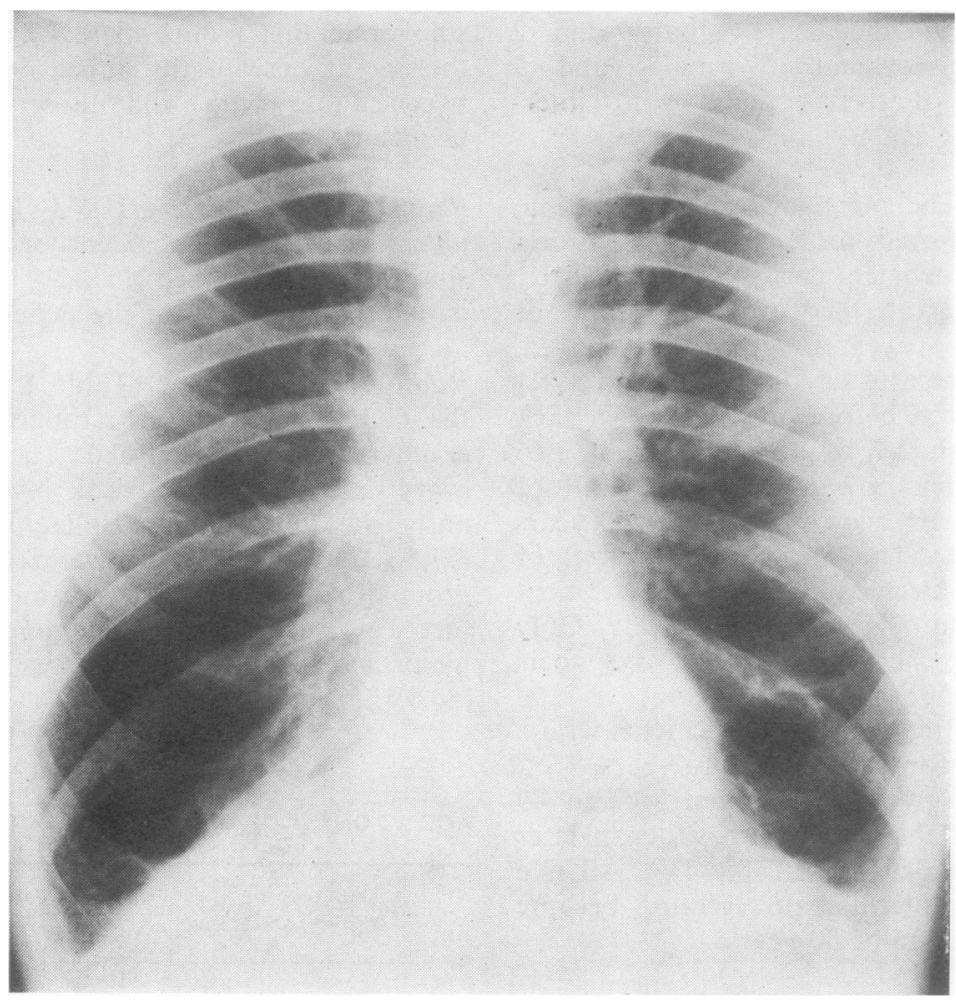

FIG. 2. Chest radiograph of a deficient homozygote showing symmetrical, predominantly lower zone emphysema.

Pulmonary physiology The results in the 16 deficient patients are summarized in Table VI. In general the findings were similar in all groups.

Relatives The 68 relatives consisted of 36 males and 32 females whose ages ranged from 3 to 72 years. Of the 59 blood relatives 6 were $\alpha_{1}$ antitrypsin deficient. Three aged under 35 years $(16$, 18 , and 34 years) were symptom free while the three aged over 35 years $(36,42$, and 49 years) had undoubted emphysema. Three of the $33 \stackrel{\circ}{\circ}$ relatives with intermediate levels and one of the 20 with non-deficient levels had chronic bronchitis. A history of extrinsic asthma was found ${ }^{\circ}$ in two relatives aged under 30 years-one with $\vec{\Phi}$ intermediate (son of case $5-\mathrm{IV}^{2}$ in Fig. 3), the $\frac{?}{\mathrm{O}}$ other with a normal T.I.C. level. The remaining $\varrho$ 47 relatives were free from respiratory disease. 
T A B L E V I

PULMONARY PHYSIOLOGY IN $a_{1}$ ANTITRYPSIN DEFICIENT PATIENTS

\begin{tabular}{|c|c|c|c|c|c|c|}
\hline \multirow{2}{*}{ Patient } & \multirow{2}{*}{$\underset{\%}{\mathrm{FEV}_{1} / \mathrm{FVC}}$} & \multirow{2}{*}{ RV/TLC } & \multicolumn{2}{|c|}{ TLCo (rest) } & \multirow{2}{*}{$\frac{\mathrm{PaO}_{2}}{(\mathrm{mmHg})}$} & \multirow{2}{*}{$\frac{\mathrm{PaCO}_{8}}{(\mathrm{mmHg})}$} \\
\hline & & & Pred. & Obs. & & \\
\hline $\begin{array}{r}1 \\
2 \\
3 \\
4 \\
5 \\
6 \\
7 \\
8 \\
9 \\
10 \\
11 \\
12 \\
13 \\
14 \\
15 \\
16\end{array}$ & $\begin{array}{l}22 \\
37 \\
32 \\
42 \\
50 \\
24 \\
31 \\
32 \\
43 \cdot 8 \\
33 \\
40 \\
33 \\
35 \cdot 4 \\
23 \\
33 \cdot 4 \\
35\end{array}$ & $\begin{array}{l}71 \cdot 5 \\
52 \\
80 \cdot 6 \\
72 \\
65 \cdot 2 \\
56 \\
72 \\
57 \\
78 \cdot 2 \\
57 \\
72 \\
67 \\
53 \\
54 \\
55 \\
78\end{array}$ & $\begin{array}{l}23 \cdot 2 \\
22.8 \\
19.6 \\
16.5 \\
34.4 \\
16.7 \\
17.2 \\
20.0 \\
17.5 \\
18.9 \\
20.0 \\
16.7 \\
20.4 \\
20.0 \\
14.0 \\
20.0\end{array}$ & $\begin{array}{r}9.3 \\
10.6 \\
9.1 \\
6.0 \\
17.31 \\
11.2 \\
5.3 \\
9.9 \\
11.6 \\
4.0 \\
11.9 \\
8.8 \\
4.9 \\
11.2 \\
6.0 \\
5.6\end{array}$ & $\begin{array}{l}\frac{64}{72} \\
41 \\
88 \\
\frac{47}{47} \\
\overline{72} \\
\overline{67} \\
75 \\
88 \\
87 \\
92 \cdot 8 \\
40\end{array}$ & $\begin{array}{l}\frac{40}{33} \\
61 \cdot 5 \\
28 \\
\frac{42}{42} \\
\frac{40}{38} \\
38 \\
35 \\
37 \\
33 \cdot 5 \\
46\end{array}$ \\
\hline
\end{tabular}

Single breath method.

Brief clinical details of cases 5, 9, and 13 are given together with their respective family pedigrees (Figs. 3, 4, and 5).

\section{CASE HISTORIES}

CASE 5 C.K., male aged 38.

History Well until 11 years previously when he developed extrinsic allergic asthma. Later noticed cough and sputum which improved after he stopped smoking 40 cigarettes per day. Four years ago noticed dyspnoea on exertion without wheezing. Asthma well controlled with corticosteroids and disodium chromoglycate.

\section{Family history See Figure 3.}

Examination Well-built man. Diminished breath sounds with faint expiratory wheeze. No other abnormality.

Investigations Chest radiograph shows low flat diaphragms, large retrosternal translucent zone, and attenuation of mid-lung vessels to lower zones. Pulmonary physiology (predicted values in parentheses): FRC $10,400 \mathrm{ml}(4,250 \mathrm{ml})$; TLC $13,800 \mathrm{ml}(7,620$ ml) ; RV/TLC $65.2 \%(30 \%)$; FVC 4,400 ml (5,300 $\mathrm{ml}) ;$ FEV $_{1} 2,200 \mathrm{ml}(4,240 \mathrm{ml}) ; \mathrm{FEV}_{1} /$ FVC $50 \%$ (80\%); TLco (rest) $17.3 \mathrm{ml} \mathrm{CO} / \mathrm{min} / \mathrm{mmHg}$-single breath method. Arterial blood gases: $\mathrm{PCO}_{2} 28 \mathrm{mmHg}$; $\mathrm{PO}_{2} 88 \mathrm{mmHg}$. Protein electrophoresis: absence of $\alpha_{1}$ globulin fraction. $\alpha_{1}$ antitrypsin level $23 \mathrm{mg} \%$.

Diagnosis Emphysema and extrinsic allergic asthma.

Pedigree ( $a_{1}$ antitrypsin levels in parentheses)

$I_{1}$ d. aged 54 【Carcinoma of the larynx

$I_{2}$ d. aged 83 No known respiratory disease

$I_{3}$ d. aged 70 No known respiratory disease

I, d. aged 89 No known respiratory disease

\begin{tabular}{|c|c|c|}
\hline II $_{1}$ & aged 66 & Well (110 mg \%) \\
\hline $\mathbf{I I}_{2}$ & aged 61 & Well (115 mg \%) \\
\hline $\mathrm{IIII}_{1}$ & Wife of & proband (400 $\mathrm{mg} \%)$ \\
\hline IIII $_{2}$ & aged 38 & Proband ( $23 \mathrm{mg} \mathrm{\% )}$ \\
\hline IIII $_{3}$ & aged 40 & Well (110 $\mathrm{mg} \%$ ) \\
\hline $\mathrm{IIII}_{4}$ & aged 34 & Symptom-free when seen $(35 \mathrm{mg} \%)^{1}$ \\
\hline III- & aged 36 & $\begin{array}{l}\text { Emphysema, mainly basal; disability } \\
\text { minimal; smoked } 15 \text { cigarettes per } \\
\text { day ( } 22 \mathrm{mg} \mathrm{\%})\end{array}$ \\
\hline $\begin{array}{l}\mathrm{III}_{6} \\
\text { IV }_{1-4}\end{array}$ & $\begin{array}{l}\text { Wife of } \\
\text { aged un }\end{array}$ & $\begin{array}{l}\mathrm{III}_{5}(230 \mathrm{mg} \%) \\
\text { well }(125 \mathrm{mg} \% ; 115 \mathrm{mg} \% ; 135 \\
\text { mg } \% ; 135 \mathrm{mg} \%\end{array}$ \\
\hline
\end{tabular}

CASE 9 G.P., female aged 36 .

History Progressive dyspnoea with cough and mucoid sputum for six years. Smoked 50 cigarettes per day.

\section{Family history See Figure 4.}

Examination Thin. Overinflated chest with diminished breath sounds.

Investigations Chest radiograph shows low flat diaphragms and large retrosternal translucent zone. Widespread attentuation of mid-lung vessels with lower zone bullae. Pulmonary function tests (predicted values in parentheses): VC $1,950 \mathrm{ml}(3,760 \mathrm{ml})$; FRC $7,630 \mathrm{ml}$ $(3,140 \mathrm{ml}) ;$ TLC $8,930 \mathrm{ml}(5,510 \mathrm{ml}) ; \mathrm{RV} / \mathrm{TLC} 78.2 \%$ $(31.8 \%)$; FVC 1,600 ml $(3,760 \mathrm{ml}) ;$ FEV $_{1} 700 \mathrm{ml}(3,020$ $\mathrm{ml}$ ); FEV 1 FVC $43.8 \%$ (80\%); TLco (rest) $11.6 \mathrm{ml}$ $\mathrm{CO} / \mathrm{min} / \mathrm{mmHg}$ at minute volume of $13.81 / \mathrm{min} ;(17.5$ $\mathrm{ml} \mathrm{CO} / \mathrm{min} / \mathrm{mmHg}) ; \%$ extraction CO $32 \%(47 \%)$. Arterial blood gases: $\mathrm{PCO}_{2} 40 \mathrm{mmHg} ; \mathrm{Po}_{2} 72 \mathrm{mmHg}$. Protein electrophoresis: absent $a_{1}$ globulin fraction. T.I.C. $0 \cdot 28 \mathrm{mg} / \mathrm{ml}$.

Diagnosis Emphysema and chronic bronchitis.

III, has recently developed dyspnoea. 

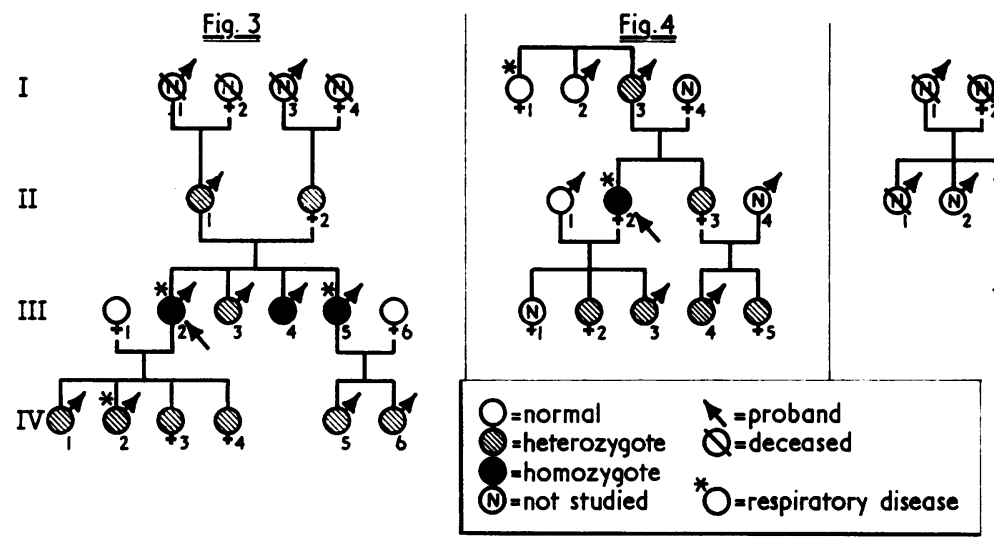

ig. 5

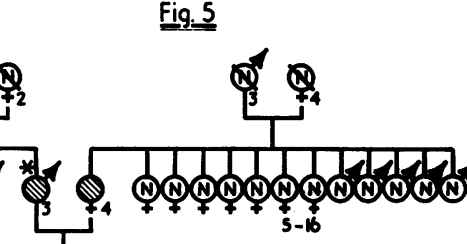

Pedigree (T.I.C. levels in parentheses)

$\begin{array}{rrl}\mathrm{I}_{1} & \text { aged 73 } & \text { Mild chronic bronchitis }(0.86 \mathrm{mg} / \mathrm{ml}) \\ \mathrm{I}_{2} & \text { aged 73 } & \text { On oestrogen therapy }(1.09 \mathrm{mg} / \mathrm{ml}) \\ \mathrm{I}_{3} & \text { aged 67 } & \text { On oestrogen therapy }(1.00 \mathrm{mg} / \mathrm{ml}) \\ \mathrm{II}_{1} & \text { aged 40 } & \text { Husband of proband }(0.93 \mathrm{mg} / \mathrm{ml}) \\ \text { II }_{2} & \text { aged 36 } & \text { Proband }(0.28 \mathrm{mg} / \mathrm{ml}) \\ \text { II }_{3} & \text { aged } 40 & \text { Well }(0.85 \mathrm{mg} / \mathrm{ml}) \\ \text { III }_{1} & \text { aged 2 } & \text { Well } \\ \text { III }_{2} & \text { aged } 9 & \text { Well }(0.70 \mathrm{mg} / \mathrm{ml}) \\ \text { III }_{3} & \text { aged 10 } & \text { Well }(0.70 \mathrm{mg} / \mathrm{ml}) \\ \text { III }_{4} & \text { aged 6 } & \text { Well }(0.78 \mathrm{mg} / \mathrm{ml}) \\ \text { III }_{5} & \text { aged 12 } & \text { Well }(0.82 \mathrm{mg} / \mathrm{ml})\end{array}$

CASE 13 J.E., male aged 39.

History Cough, sputum, and progressive dyspnoea for six years. Unable to continue work as a professional dancer. Smoked 30 cigarettes per day.

\section{Family history See Figure 5.}

Examination Thin man with hyperinflated chest and diminished breath sounds.

Investigations Chest radiograph shows low flat diaphragm, large retrosternal translucent zone, narrow vertical heart, large main pulmonary vessels and attenuated mid-lung vessels, particularly in the lower zones. Pulmonary function tests: FRC $5,400 \mathrm{ml}(4,250$ $\mathrm{ml}) ;$ TLC 7,950 ml (7,620 ml); RV/TLC $53.0 \%(30.4 \%)$; FVC 3,400 ml (5,300 ml); FEV 1 1,200 ml (4.240 ml); FEV $_{1} /$ FVC $35.4 \%(80.0 \%)$; TLco (rest) $4.9 \mathrm{ml} \mathrm{CO} / \mathrm{min} /$ $\mathrm{mmHg}$ at minute volume of $6.651 / \mathrm{min}(20.4 \mathrm{ml} \mathrm{CO} / \mathrm{min} /$ $\mathrm{mmHg}) ; \%$ extraction CO $30.2(46 \%)$. Arterial blood gases: $\mathrm{PCO}_{2} 35 \mathrm{mmHg} ; \mathrm{PO}_{2} 88 \mathrm{mmHg}$. Protein electrophoresis: diminished $a_{1}$ globulin fraction. T.I.C. $0 \cdot 18$ $\mathrm{mg} / \mathrm{ml}$.

Progress Had a plication of right lower lobe with minimal improvement. Losing weight.
Diagnosis Emphysema and chronic bronchitis.

Pedigree (T.I.C. levels in parentheses)

$I_{1}$ d. aged 74 No known respiratory disease

$I_{2} d$. aged 72 No known respiratory disease

$I_{3}$ d. aged 66 No known respiratory disease

$I_{4}$ d. aged 64 No known respiratory disease

II $_{1}$ d. -

$\mathrm{II}_{2} \quad-$

$\mathrm{II}_{3}$ aged 71

II 4 aged 72

II $_{5-16}$

Cerebral tumour

Well

Chronic bronchitis (C.79 mg/ml)

Well $(0.79 \mathrm{mg} / \mathrm{ml})$

Two sisters had pulmonary tuber culosis; no other evidence of respiratory disease

III $_{1}$ aged 39 Proband $(0.18 \mathrm{mg} / \mathrm{ml})$

$\mathrm{III}_{2}$ aged 49 Emphysema; 12-year history of progressive dyspnoea; severelyठ incapacitated and losing weight; smokes 30 cigarettes per day $\left(0.38_{0}\right.$ $\mathrm{mg} / \mathrm{ml}$ )

$\mathrm{III}_{3}$ aged 46 Wife of $\mathrm{III}_{2}(1.0 \mathrm{mg} / \mathrm{ml})$

IV $_{1}$ aged 23 Well $(0.84 \mathrm{mg} / \mathrm{ml})$

IV, aged 13 Well $(0.84 \mathrm{mg} / \mathrm{ml})$

$\mathrm{IV}_{3}$ aged 20 Well $(0.83 \mathrm{mg} / \mathrm{ml})$

\section{DISCUSSION}

Alpha $_{1}$ antitrypsin forms the major component of the $\alpha_{1}$ globulin fraction seen on serum electrophoresis. First isolated by Schultze, Heide, and ${ }^{\omega}$ Haupt (1962), its physical characteristics are now well described (Schultze et al., 1963). It is respon-o은 sible for approximately $90 \%$ of the total serum T.I.C., the remaining $10 \%$ being mainly in the form of an $\alpha_{2}$ macroglobulin. The role of $\alpha_{1}$ antitrypsin in healthy subjects is as yet unknown. Raised levels have been reported in association $\frac{\text { }}{\mathbb{D}}$ with malignant disease (Clark, Clifton, and@ Newton, 1948), pregnancy (Faarvang and 
Lauritsen, 1963), and in response to a variety of stimuli including infections (Jacobsson, 1955), typhoid vaccine (Kueppers, 1968), oestrogens (Schumacher and Pearl, 1968), surgical stress, and corticosteroids (Faarvang and Lauritsen, 1963).

This study has confirmed the association between a genetically determined deficiency of $\alpha_{1}$ antitrypsin and pulmonary emphysema. Sixteen (18.4\%) of the 87 patients with clinical, radiological, and physiological evidence of emphysema had absent $\alpha_{1}$ globulin fractions on serum electrophoresis and unequivocally deficient T.I.C. levels of $0.33 \mathrm{mg} / \mathrm{ml}$ or less, 11 to $30 \%$ of the mean level in controls. This incidence of $18.4 \%$ in a highly selected group of patients is greater than that found in other series. However, methods of selection and investigation have differed widely, making comparisons difficult. The previous highest incidence was $11 \%$ of 55 individuals with severe airways obstruction reported by Pedersen, Weeke, and Georg (1969) whose criteria most closely matched those of this study. It is probable, as these authors implied, that the more stringent the criteria used the higher the incidence obtained is likely to be, an observation that would apply particularly to this study. Local environmental factors cannot be implicated as the patients came from many different geographical areas both urban and rural.

The clinical picture of emphysema in patients with $\alpha_{1}$ antitrypsin deficiency is well documented (Talamo, Blennerhassett, and Austen, 1966) and shows certain features not seen with emphysema in general. The most consistent difference is the much earlier age at which dyspnoea develops, usually in the third decade. The youngest recorded case is 22 years (Makino, Chosy, Valdivia, and Reed, 1970). In the present series the mean age at onset of dyspnoea was only 35 years; four-fifths of the patients in the deficient group were dyspnoeic before the age of 40 years and all before the age of 50 years. Considering all 87 emphysema patients, the younger the age at which symptoms developed, the higher was the incidence of $\alpha_{1}$ antitrypsin deficiency: among the 20 patients who became dyspnoeic before the age of 40 years, $60 \%$ were $\alpha_{1}$ antitrypsin deficient.

Similar observations were made in the six relatives also found to be $\alpha_{1}$ antitrypsin deficient. Three, aged 38 to 49 years, had undoubted emphysema while the other three, all under 35 years of age, were symptom-free though not fully investigated. Recent evidence (Levine, Talamo, Shannon, and Kazemi, 1970) suggests that detailed physiological evaluation of lung function may detect abnormalities in asymptomatic patients with $\alpha_{1}$ antitrypsin deficiency and that altered distribution of pulmonary perfusion using xenon 133 is the earliest detectable defect. Thus, it appears that the majority of subjects with $\alpha_{1}$ antitrypsin deficiency, approximately $90 \%$ according to Eriksson (1965), are likely to develop emphysema before the age of 50 years.

Kowalyshyn and Sataline (1969) stated that emphysema associated with $\alpha_{1}$ antitrypsin deficiency occurs predominantly in females, but this has not been confirmed in most series. Although 10 of $13 \alpha_{1}$ antitrypsin deficient patients with emphysema reported by Welch, Reinecke, Hammersten, and Guenter (1969) were women, these authors commented that this might not be a true representation of sex distribution, as young women with emphysema were sufficiently unusual to prompt referral for consultation. In the present series a great excess of men was found among deficient and non-deficient emphysema patients, the sex ratio being $7: 1$ in both groups.

Eriksson (1965) found emphysema in $88 \%$ of men with $\alpha_{1}$ antitrypsin deficiency but in only $50 \%$ of women. This suggests that either $\alpha_{1}$ antitrypsin deficient females are protected against the development of emphysema or that exogenous factors, affecting men predominantly, are important.

The importance of cigarette smoking to the early development of symptoms in patients with emphysema and $\alpha_{1}$ antitrypsin deficiency has been emphasized (Kueppers, Fallat, and Larson, 1969). This may have been relevant in the case mentioned by Townley, Ryning, Lynch, and Brody (1970); this was a 46-year-old male nonsmoker who, though a deficient homozygote, showed no evidence of emphysema. In the present study the mean age at onset of dyspnoea in the deficient group was 35.6 years, yet symptoms did not develop until the age of 49 years in the only non-smoker in the group. Among non-deficient patients no such difference between smokers and non-smokers was apparent.

It has been reported (Talamo, Allen, Kahan, and Austen, 1968) that chronic bronchitis occurs infrequently in association with emphysema in $\alpha_{1}$ antitrypsin deficient subjects. However, a review of the literature shows that the majority of patients do have the features of chronic bronchitis, though clinical details are often sparse and evaluation difficult. Sixteen (70\%) of Eriksson's (1965) 23 patients had produced sputum for five years or more while $10(77 \%)$ of 13 patients reported by Welch et al: (1969) were said to have 
bronchitis. In the present study $75 \%$ of the $\alpha_{1}$ antitrypsin deficient patients and $78 \%$ of all patients gave a history of chronic bronchitis.

It is of interest to note that a history of extrinsic allergic asthma, a disease in which genetic factors are probably important, was found in case 5 and in one of his sons who was a heterozygote. A similar family history of extrinsic allergic asthma was recorded in two of Eriksson's deficient homozygotes (1965) and in four members of the family reported by Townley et al. (1970).

A high incidence of peptic ulcer has been reported in patients with a variety of chronic bronchopulmonary diseases (Mitchell and Filley, 1964). Eriksson (1965) found an incidence of $30 \%$ in deficient homozygotes with emphysema and similar results have since been obtained (Lieberman, 1969). By comparison, in this study, though $15 \%$ of non-deficient patients gave a history of peptic ulcer none of the deficient group did so.

The radiographic appearances of emphysema in $\alpha_{1}$ antitrypsin deficient patients have been described in detail (Welch et al., 1969) and agree closely with those seen here. Involvement was invariably symmetrical and maximal in the lower zones. Bullae were common. These changes differed from those seen in non $\alpha_{1}$ antitrypsin deficient patients in whom symmetry was infrequent and upper zone distribution common. However, a clear-cut distinction was not always apparent ; $19(28.8 \%)$ of the non-deficient group of patients also exhibited lower zone predominance. Nevertheless, it is evident that $\alpha_{1}$ antitrypsin deficiency should be suspected in patients presenting before the age of 50 years with progressive dyspnoea and radiographic evidence of symmetrical lower zone emphysema.

Radioxenon studies confirmed the impairment of ventilation and perfusion to the lower zones in the $\alpha_{1}$ antitrypsin deficient group of patients. Other tests of pulmonary function differed little between the three groups.

Whereas the homozygous deficient state was readily identified on the basis of T.I.C. levels alone, using Eriksson's criteria, no such precise correlation existed between the heterozygous state and intermediate T.I.C. levels. Family studies indicated that several 'genetic heterozygotes' had T.I.C. levels of between 0.8 and 0.87 $\mathrm{mg} / \mathrm{ml}$. Lieberman (1969) and Kueppers (1967), using similar techniques, have also recorded T.I.C. levels of $0.85 \mathrm{mg} / \mathrm{ml}$ or greater in true heterozygotes. It has been shown that heterozygotes, unlike deficient homozygotes, are capable of increasing their T.I.C. levels to within the normal range in response to certain stimuli (Kueppers, 1968). This was probably the case in the male parent of the homozygous patient who had a T.I.C. level of $1.00 \mathrm{mg} / \mathrm{ml}$ and who was being treated with oestrogens for carcinoma of the prostate.

In view of the possible overlap in T.I.C. levels in a proportion of heterozygotes and normal subjects, accurate distinction between the two is difficult and leads to an underestimate of the frequency of the heterozygous state. Eriksson 0 (1965) found a frequency of $4.7 \%$ in a Scandi- 9 navian population and Kueppers, Briscoe, and $O$ Bearns (1964) $2.1 \%$ in a small white population in Georgia, U.S.A. Using similar techniques in the present study, we found that $10 \%$ of controls had intermediate T.I.C. levels, the number rising to $14 \%$ if the upper limit is raised to $0.9 \mathrm{mg} / \mathrm{ml}$. Kueppers, Fallat, and Larson (1969), in a followup study using 'antigen antibody crossed electrophoresis', a technique based on qualitative rather than quantitative differences in globulins which, they claim, distinguishes reliably between heterozygotes and normal individuals, found an incidence of 9 to $14 \%$ of heterozygotes in their controls.

Due partly to the difficulties in recognizing the heterozygous state, its role in the development of pulmonary disease has remained in dispute. Eriksson (1965) and other workers failed to find any evidence to associate the heterozygous state with lung disease in general or emphysema in particular. However, using antigen antibody crossed electrophoresis, Kueppers et al. (1969) found that $25.5 \%$ of their patients with 'obstructive lung disease' compared to 9 to $14 \%$ of their controls were heterozygotes whereas, when T.I.C. estimations alone had been used in an earlier series, they had found no heterozygotes among 99 patients with emphysema. Lieberman (1969) measured the T.I.C. levels of 66 patients with $\frac{7}{O}$ emphysema and found $15.2 \%$ of heterozygotes and $10.6 \%$ of deficient homozygotes. These $N$ authors did not have a control group but regarded a T.I.C. level of $0.85 \mathrm{mg} / \mathrm{ml}$ as the upper limit of normal.

Unfortunately, assessment of these findings is complicated by the fact that the terms emphysema

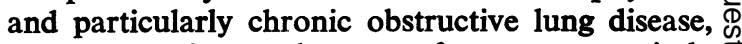
so commonly used, are often not precisely defined. In the present series there was no evident association between the heterozygous state and $\frac{O}{\mathbb{D}}$ either chronic bronchitis or emphysema.

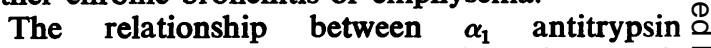
deficiency and the pathogenesis of emphysema is 
still conjectural and it remains to be proved whether this deficiency is causally related to the development of emphysema or merely acts as a genetic marker. It is possible that $\alpha_{1}$ antitrypsin normally protects alveolar septa against enzymatic digestion. Gross et al. (1965) showed that in rats panacinar emphysema could be produced by intratracheal instillation of the proteolytic enzyme papain and this has recently been confirmed in dogs (Pushpakom et al., 1970). The $\alpha_{1}$ globulins inhibit not only trypsin but also chymotrypsin, plasmin, thrombin and elastase (Rimon, Shamash, and Shapiro, 1966 ; Turino et al., 1969). Kueppers and Bearns (1966) observed that $\alpha_{1}$ antitrypsin inhibits the proteolytic enzymes released by human leucocytes. It seems possible that these enzymes are being continually released in the alveoli by macrophages and other phagocytic cells and that failure to inhibit them may lead to increased breakdown or disturbed resynthesis of alveolar connective tissue proteins. The continual physical stress of the lung during normal breathing might be sufficient to precipitate the structural defects in this organ leading to emphysema.

Although curative treatment is not possible, early detection is important so that factors such as cigarette smoking and infection, which may increase lung destruction, can be eliminated. Fortunately the clinical presentation and the pattern of serum electrophoresis in affected individuals appears to be sufficiently characteristic to suggest the diagnosis which can be readily confirmed by $\alpha_{1}$ antitrypsin estimation. Should the heterozygous state also be shown to predispose to pulmonary emphysema and to occur commonly in the population, then identification of all affected persons might become necessary.

We wish to thank Professor J. G. Scadding for his considerable help and guidance. We are most grateful to the physicians at the Brompton Hospital for allowing us to study their patients, to Dr. G. Simon for examining the chest radiographs, and to Mrs. C. O'Hanlon for undertaking most of the T.I.C. estimations. We are also most indebted to the late Dr. A. Kuper for helping make this study possible, and to the Chest and Heart Association for their generous grant.

\section{REFERENCES}

Clark, D. G., Clifton, E. E., and Newton, B. L. (1948). Antiproteolytic activity of human serum with particular reference to its changes in the presence and considerations of its use for detection of malignant neoplasia. Proc. Soc. exp. Biol. (N.Y.), 69, 276.
Definition and Classification of Chronic Bronchitis. A report to the Medical Research Council by their Committee on the Aetiology of Chronic Bronchitis (1965). Lancet, 1, 775.

Eriksson, S. (1965). Studies in $\alpha_{1}$ antitrypsin deficiency. Acta med. scand., 177, Suppl. 432.

Faarvang, H. J., and Lauritsen, O. S. (1963). Relationship between serum concentration and urinary output of trypsin inhibitor after cortisone administration. Scand. J. clin. Lab. Invest., 15, 483.

Gross, P., Pfitzer, E. A., Tolker, E., Babyak, M. A., and Kaschak, M. (1965). Experimental emphysema. Arch. environm. Hlth, 11, 50.

Jacobsson, K. (1955). Studies on the determination of fibrinogen in human blood plasma. II. Studies on the trypsin and plasmin inhibitors in human blood serum. Scand. J. clin. Lab. Invest., 7, Suppl. 14, 55.

Kowalyshyn, T., and Sataline, L. R. (1969). Familial emphysema associated with antitrypsin deficiency. Dis. Chest, 55, 285.

Kueppers, F. (1967). Immunologic assay of $\alpha_{1}$ antitrypsin in deficient subjects and their families. Hum. Genet., $5,54$.

(1968). Genetically determined differences in the response of $\alpha_{1}$ antitrypsin levels in human serum to typhoid vaccine. Hum. Genet., 6, 207.

- and Bearns, A. G. (1966). A possible experimental approach to the association of hereditary $\alpha_{1}$-antitrypsin deficiency and pulmonary emphysema. Proc. Soc. exp. Biol. (N.Y.), 121, 1207.

- Briscoe, W. A., and Bearns, A. G. (1964). Hereditary deficiency of serum $\alpha_{1}$ antitrypsin. Science, 146, 1678.

- Fallat, R., and Larson, R. K. (1969). Obstructive lung disease and $\alpha_{1}$ antitrypsin deficiency gene heterozygosity. Science, 165, 899.

Laurell, C. B., and Eriksson, S. (1963). The electrophoretic $\alpha_{1}$-globulin pattern of serum in $\alpha_{1}$-antitrypsin deficiency. Scand. J. clin. Lab. Invest., 15, 132.

Levine, B. W., Talamo, R. C., Shannon, D. C., and Kazemi, H. (1970). Alteration in distribution of pulmonary blood flow: an early manifestation of alpha -antitrypsin $_{1}$ deficiency. Ann. intern. Med., 73, 397.

Lieberman, J. (1969). Heterozygous and homozygous

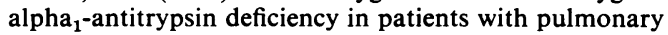
emphysema. New Engl. J. Med., 281, 279.

Louis (1837). Recherches sur l'emphysème des poumons. Mém. Soc. méd. d'Obs. (Paris), 1, 160.

MacNamara, J., Prime, F. J., and Sinclair, J. D. (1959). An assessment of the steady-state carbon monoxide method of estimating pulmonary diffusing capacity. Thorax, 14, 166.

Makino, S., Chosy, L., Valdivia, E., and Reed, C. E. (1970). Emphysema with hereditary $\alpha_{1}$ antitrypsin deficiency masquerading as asthma. J. Allergy, 46, 40.

Mancini, G., Vaerman, J. P., Carbonara, A. O., and Hermans, J. F. (1964). Protides of the Biological Fluids, edited by $\mathrm{H}$. Peeters; Proc. 11 th Colloquium, Bruges, 1963. pp. 370-373. Elsevier, Amsterdam.

Mannell, T. J., Prime, F. J., and Smith, D. W. (1966). A practical method of using radioactive xenon for investigating regional lung function. Scand. J. resp. Dis., Suppl. 62, 41.

Mitchell, R. S., and Filley, G. F. (1964). Chronic obstructive bronchopulmonary disease. 1. Clinical features. Amer. Rev. resp. Dis., 89, 360. 
Ogilvie, C. M., Forster, R. E., Blakemore, W. S., and Morton, J. W. (1957). A standardised breath-holding technique for the clinical measurement of the diffusing capacity of the lung for carbon monoxide. J. clin. Invest., 36, 1.

Pedersen, J. T., Weeke, B., and Georg, J. (1969). Lung disease and $\alpha_{1}$-antitrypsin deficiency. Dan. med. Bull., 16, 283.

Pushpakom, R., Hogg, J. C., Woolcock, A. J., Angus, A. E., Macklem, P. T., and Thurlbeck, W. M. (1970). Experimental papain-induced emphysema in dogs. Amer. Rev. resp. Dis., 102, 778.

Reid, L., and Millard, F. J. C. (1964). Correlation between radiological diagnosis and structural lung changes in emphysema. Clin. Radiol., 15, 307.

Rimon, A., Shamash, Y., and Shapiro, B. (1966). The plasmin inhibitor of human plasma IV. Its action on plasmin, trypsin, chymotrypsin and thrombin. J. biol. Chem., 241, 5102.

Scadding, J. G. (1969). Emphysema. Proc. roy. Soc. Med., 62, 1023 .

Schultze, H. E., Heide, K., and Haupt, H. (1962). $\alpha_{1}$ antitrypsin aus humanserum. Klin. Wschr., 40, 427.

- Heimburger, N., Heide, K., Haupt, H., Störiko, K., and Schwick, H. G. (1963). Preparation and characterization of $\alpha_{1}$-trypsin inhibitor and $\alpha_{2}$-plasmin inhibitor of human serum. In Proceedings of the 9th Congress of the European Society of Haematology, Lisbon, 1963, Part II/2, p. 1315. Karger, Basle and New York.

Schumacher, G. F. B., and Pearl, M. J. (1968). Alpha antitrypsin in cervical mucus. Fertil. and Steril., 19, 91.

Simon, G. (1964). Radiology and emphysema. Clin. Radiol., $15,293$.

Talamo, R. C., Allen, J. D., Kahan, M. G., and Austen,

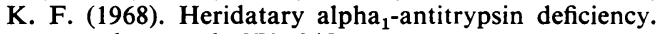
New Engl. J. Med., 278, 345.

- Blennerhassett, J. B., and Austen, K. F. (1966). Familial emphysema and $a$-antitrypsin deficiency. New Engl. J. Med., 275, 1301.
Townley, R. G., Ryning, F., Lynch, H., and Brody, A. W. (1970). Obstructive lung disease in hereditary $\alpha_{1}-\frac{\bar{\sigma}}{\bar{\omega}}$. antitrypsin deficiency. J. Amer. med. Ass., 214, 325.

Turino, G. M., Senior, R. M., Garg, B. D., Keller, S.』ฉ Levi, M. M., and Mandl, I. (1969). Serum elastase@ inhibitor deficiency and $\alpha_{1}$-antitrypsin deficiency in patients with obstructive emphysema. Science, 165, 709. $\vec{\circ}$

Welch, M. H., Reinecke, M. E., Hammersten, J. F., and Guenter, C. A. (1969). Antitrypsin deficiency in pul- $\vec{\omega}$ monary disease: the significance of intermediate levels. Ann. intern. Med., 71, 533.

\section{ADDENDUM}

Since this paper was submitted for publication further article on this subject has been published ${ }^{\circ}$ [Hutchinson, D. C. S., Cook, P. J. L., Barter, C. E.. $\vec{z}$ Harris, H., and Hugh-Jones, P. (1971). Pulmonaryo emphysema and $\alpha_{1}$ antitrypsin deficiency. British $\stackrel{\Phi}{\rightrightarrows}$ Medical Journal, 1, 689]. They studied 72 patients with radiographic evidence of pulmonary emphys- $\frac{\mathbb{D}}{-}$ ema, using criteria similar to those described in $\overrightarrow{0}$ this paper but found a lower incidence $(11.1 \%) \underset{ }{-}$ of $\alpha_{1}$ antitrypsin deficiency. The T.I.C. levels which they reported were appreciably higher, botho in the controls and in the patients classified as 'deficient', than those found in this investigation and those recorded by other workers.

The clinical and radiological features in their eight patients with $\alpha_{1}$ antitrypsin deficiency are을 similar to those described in this article. How ever, the horizontal striations at the costophrenic angles which they observed in the chest radiographs were not evident in the present series. 